\title{
Does Locally Produced Food Create Loyalty?: An Investigation On Locavore Attitude As Control VARIABLE
}

Güzide Öncü EROĞLU PEKTAŞ ${ }^{1}$, Mehmet YÜKSEL $^{2}$, Ahmet DURMAZ $^{3}$

\begin{abstract}
After locavore was chosen as "the best word of the year" in 2007 , its popularity increased gradually. Today great number of locavores consciously prefer locally produced food for the benefit of themselves and their community. Undoubtedly this conscious movement has its consequences in marketing discipline. Accordingly, this paper is purposed to examine the how locavore perceptions affect loyalty towards retailers that sell locally produced food. In this context, a survey was applied to people residing in Istanbul and Kocaeli districts to measure the robustness of these effects. Furthermore, attitude towards locavore is used as a control variable to reveal to what extend locavorism affects these proposed connections. According to results, for participants with low attitude, Social Responsibility and Health Consciousness variables have significant effect on local retailer shopping loyalty. However, for participants with high attitude, all independent variables proved to have substantial effect on local retailer shopping loyalty. As the first empirical study in Turkey on the subject, this paper will provide important insight to academia and practicioners due to today's ever-increasing consciousness in green marketing.
\end{abstract}

Keywords: Locavore, Locally produced foods, Health consciousness, Traceability, Price consciouness, Taste, Social Responsibility.

\section{INTRODUCTION}

The $19^{\text {th }}$ and $20^{\text {th }}$ centuries brought about an unimaginable revolution on food and its range. Until then most of people's daily nutrition was sourced in the region where they lived and nearly everything was local. Even the foods such as coffee, tea and spices were exotic. The majority of the foods consumed in the world were sourced locally therefore they were not part of the average person's daily diet. Developments in trade put an end this situation and it simplified people's life and nutrition chains by presenting them miscellaneous, cheaper and faster foods (Giovannucci, Barham and Pirog, 2009).

Rapid changes in diets and lifestyles that have occurred with industrialization, urbanization and economic development, have accelerated over the past century. This is having a significant impact on the health and nutritional status of populations. While standards of living have improved, food availability has expanded and become more diversified there have also been significant negatory outcomes in terms of inappropriate dietary patterns and decreased physical activities and a corresponding increase in diet-related chronic (WHO/FAO Expert Consultation, 2003). The corruptions in foods and food sector has directed people to discover healthy foods resources. Solution was hidden in their old eating habits and it will provide a renaissance for locally grown foods.

The rising demand and popularity of locally grown foods has been a common topic in these days and a new term was deemed word of the year for 2007 by Oxford: "Locavore" (Conner et al., 2009). The origin of the term is attributed to Jessica Prentice, a chef and food writer, who first used the "locavore" term on World Environment Day (June 5) in 2005 (Quinn, 2013). Locavore stands for prefering locally grown foods from local suppliers in short. Consumers who are named locavores prefer to shop for food products in distribution channels that are in close proximity to where they live and that stock seasonal foods sourced from local suppliers (Spielman and Bernelin, 2015; Thomas and Mcintosh, 2013).

Locally grown foods has become increasingly in vogue. Many of the factors leading to interest in locally grown foods are based on the concerns for health, erosion of confidence in the industry, concerns with chemicals and pesticides in commercial foods and desires of people for increased taste and flavor. Because of the lack of

${ }^{1}$ Istanbul University, Maritime Transportation Engineering, guzide.pektas@istanbul.edu.tr

2 National Defence University, Barbaros Naval Science and Engineering Institute, Department of Naval Logistics Management, myuksel@dho.edu.tr

3 National Defence University, Barbaros Naval Science and Engineering Institute, Department of Naval Logistics Management, adurmaz@dho.edu.tr 
transit, locally grown produce is perceived to be fresher and tastier and consumers see buying local fresh products as safer and providing insurance against food borne diseases. For these reasons, supermarkets are started to identify farmers and producers in advertising and some of them are listing how far their food travels to the store (Stanton et al., 2012).

This research seeks to understand what motivates consumers to purchase from local retailers that provides locally grown products for its customers. By examining the literature on health conciousness, price conciousness, taste and freshness of foods, traceability and social responsibility activities, we propose a model explaining the antecedents of local retailer shopping loyalty for locavore consumers depending on their attitudes toward locally produced foods. The paper is organized as follows. First, an introduction to the locally grown foods and the increasing demand to these foods. The next section offers detailed causal effects of proposed hypothesis. In third section of this paper, information on the methodology and sampling procedures of research is given. Fourth section consists of results of the research model. The study was completed with discussions, limitations and further research suggestions.

\section{THEROTICAL BACKGROUND AND HYPOTHESIS DEVELOPMENT}

Poring over the literature, yielded some evidence about the antecedents of shopping loyalty. Thereby, five hypotheses proposed in this paper and explained in the following passages.

Recent studies indicate that diet plays an important role in prevention of diseases and living a wholesome life. Nutrition has come to the fore as one of the major determinants of diseases. Changes in dietary patterns could produce substantial gains in the population's health. Specifically, increasing consumption of fruits and vegetables, whole grains, and calciumrich foods, while reducing saturated and trans fats, added sugars and excess calories could dramatically improve people' health and well-being (Story, Kaphingst, O'Brien and Karen Glanz, 2008).

With the increasing awareness of people about their health, the concept of health consciousness has gained importance. Health consciousness defines the readiness to undertake health actions (Becker, Maiman, Kirscht, Haefner and Drachman, 1977). Health conscious consumers are aware and concerned about their wellness and are motivated to improve their health, quality of life and being self-conscious regarding health. These individuals tend to be aware of nutrition and physical fitness. Previous research has showed the interest in health as a primary motive for the purchasing food (Michaelidou and Hassan, 2008).

Nowadays, although reaching food sources and suppliers is now quite simple, this can not be said for locally grown products. Accessing locally grown products is as difficult as in old times, and these products can be offered to customers by only few suppliers. This situation impels the customer to become loyal to these few suppliers because of health reasons. Research indicate health to be the predominant motive for purchasing food and shaping attitudes and loyalty towards to food-sellers (Schifferstein and Ophuis, 1998). For instance, "lowfat" attribute enhances customer loyalty towards food brands in comparison with other alternatives due to health reasons and according to Krystallis and Chrysochou (2011).

\section{H1: Health Consciousness has a positive effect on Local Retailer Shopping Loyalty.}

Although many research have shown that a person may have a favorable attitude toward a certain behavior, he or she might not have the intention to accomplish the behavior when perceiving difficulties to do so. Becauce of that reason, the relationship between a consumer's attitude and intention is not coherent because intention may be effected by factors such as price (Yeon and Chung, 2011).

Marketing theoreticians state that customers' satisfaction and loyalty depends on quality, price and other factors. Enterprises should evaluate price impact on customers' loyalty (Virvilaite, Saladiene and Skindaras 2009). According to theoreticians, price has an important role in consumer purchase behavior and it is the most important factor, determining customer's satisfaction and loyalty. Past marketing studies also have elaborated on the links between price factors and customer loyalty (Voss, Parasuraman and Grewal, 1998; Grewal, Iyer, Krishnan and Sharma 2003; Huber, Herrmann and Wricke, 2001). Customers who estimate the value of obtained service or product think mostly about the price (Virvilaite, Saladiene and Skindaras, 2009).

In addition to being the most important factor, price is the most flexible marketing mix elements that can be quickly changed depending on product and service characteristics. This flexibility can affect customers purchase decision and as a result loyalty too. When the price of a good or product changed, customers may judge again buying that product or goods (Dovaliene and Virvilaite, 2008). 


\section{H2: Local Retailer Shopping Loyalty is associated with Price Consciousness.}

From the early ages, our behaviours towards foods seems to be heavily influenced by their taste and flavor. These predisposition tends to remain with us throughout life as we see from adult food desires that are characterized by sweet tastes and redolence (Clark and Wood, 1998). According to Food Marketing Institute's (1996) consumer survey reports, taste is the main influence on food selection. Although nutrition tendencies are affected by behavioral, sociocultural and economic variables, consumers noticed that their diet choices are generally guided by the taste of foods. The concept of taste includes the chemical senses of taste and smell. A hedonic component is included as well (Drewnowski, 1997; Gibson, 2006).

Quality is also important for food choices and generally quality was commonly associated with freshness and absence of bruises. Food quality is an important factor in creating customer satisfaction and it contributes to customer loyalty through satisfaction (Clark and Wood, 1998). If the foods are not fresh or good-looking, consumers do not prefer that products and change their supplier. According to Kearney, J.Kearney, Dunne and Gibney (2000), the most important factor perceived by adults to affect food choice is: Freshness. Hereby, fresh and tastefull foods strengthen the consumer satisfaction by emphasizing their colour, taste and smell and these factors increase the experimented feelings by consumers. So it is possible to improve the consumer loyalty by providing fresh and tasty foods for consumers (Espejel, Fandos and Flavian, 2008).

\section{H3: Freshness positively affects the Local Retailer Shopping Loyalty of customers.}

According to a survey that was performed by UK Food Standards Agency, $\% 75$ of consumers are concerned with food safety. Consumers want to get sufficient information before purchasing food therefore, enterprises have begun to pay more attention to food traceability. Traceability is defined as the ability to trace and follow a food, feed, food-producing animal or substance through all stages of production and distribution by the European Union General Food Law Regulation and food traceability is a legal requirement. The traceability system provides detailed information of food production, processing, transfer, and distribution and detailed data about animals and supply chain-related information (Chang, Tseng and Chu, 2013).

Previous studies indicate that the majority of consumers perceive both safety and quality as being related to traceability (Hobbs et al., 2005; Verbeke and Ward, 2006). By dealing with safety and quality problems through traceability systems, enterprises can hinder contaminated or low-quality products from reaching consumers. As a result, posible damages to loyalty can be prevented (Choe, Park, Chung and Moon, 2009).

\section{H4: Traceability has positive effect on Local Retailer Shopping Loyalty.}

Corporate social responsibility (CSR) has emerged in recent years as an important construct in marketing. Main reason for this growing interest in social responsibility activities is because of its influence on consumer behavior at a time when consumers are demanding more out of firms than simply a service or product at a proper price. People expect enterprises to demonstrate congruence with social values as part of their contribution to the community. Consumers evaluate a company based on whether it acts in a manner consistent with supporting the welfare of the community. According to a survey among adult consumers in 2005, it has emerged that social responsibility is the most likely factor to make people loyal followers of a brand or company (Marin,Ruiz and Rubio, 2009).

Social responsibility activities are useful in strengthening trust and the consumers' union with the company. The perception of socially responsible behaviour can strengthen commitment towards a brand or company. This explains why consumers reward these activities with loyalty towards the organizations and why support them. This greater support may materialise in stronger loyalty towards the organizations (Salmones, Crespo and Bosque, 2005). As a result, consumers are more willing to buy products from companies involved in social causes (Jones, 1997) so social responsibility activities influence loyalty (Maignan and Ferrell, 2001). Thus, we put forward the following hypothesis:

H5: Social Responsibility Activities have a direct influence on consumers' local retailer shopping loyalty. 
Figure 1: Conceptual Model

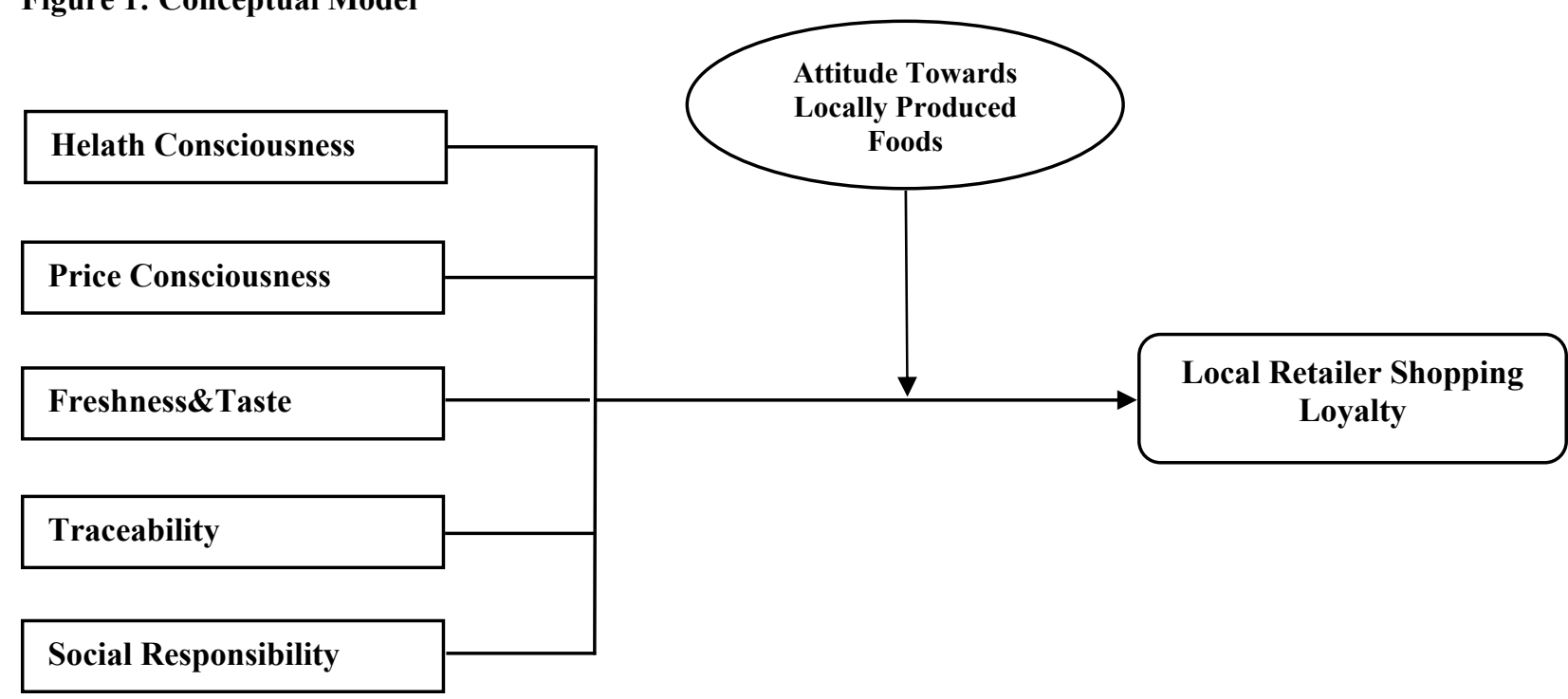

\section{METHODOLOGY}

\subsection{Data Collection and Sample}

The sample of the study was selected from the people who reside in Istanbul and Kocaeli provinces via convenience sampling method. However, while designating the sample, a special attention was paid in order to obtain a sample composed predominantly of people who at least purchase locally produced food once a month. Surveys were implemented to participants via face-to-face interviews. Responders were requested to input relevant demographic data, then answered totally 32 questions (Table 1) according to 5-likert scale ranging from, "1-strongly disagree to 5-strongly agree". At the end of a two-month effort, 299 valid observations were gathered. According to Hair, Black, Babin and Anderson (2010:635), for structural equation modeling with seven or less variables, sample size can be a minimum of 150 , providing that each variable must have minimum 0,5 communality value. Our model has seven variables with each one them having more than 0,518 communality value. Consequently, sample size of research is considered acceptable.

Sample of this research tested in terms of non-response and common biases. Non-response bias is an undesired situation that occurs when survey participants' responses significantly differ from non-respondents (Menachemi, 2011:5). In order to test whether non-response bias present in research, t-test was conducted between the early and late respondents with regard to the answers they give to survey questions. Early respondents were designated from the first 100 participants and late respondents from the last 100 participants. We observed no trace of significant difference between the early and late respondents. Thus, the research does not have response bias problem (Lages, Jap and Griffith, 2008:312). The common method variance must have test when all measures are gathered from same source. Common Method Variance (CMV) refers to the amount of false covariance shared among variables because of the common method that used in data collection (Malhotra, Kim and Patil, 2006:1865). Measurement errors might occur if common method variance is not tested. This can threaten the validity of the conclusions and produce a false explanation for the observed correlation (Podsakoff, Mackenzie, Lee and Podsakoff, 2003:879). In this research, sample was tested with Harman's single factor test (Harman, 1976:129) for investigating this issue. According to Podsakoff\& Organ (1986:533), if common method bias present, single factor will emerge from factor analysis of all items. The 
unrotated factor solution resulted in no single major factor that explaining the majority of the variance, hence common method variance will not be a problem in this research.

\subsection{Measures}

Following the implications from literature, conceptual model was formed (Figure 1) in order to investigate the effects of independent variables on the local retailer shopping loyalty of locavore users. The measures used in questionnaire were compiled from different references as shown in Table 1. The control variable of research Attitude Towards Local Products is adapted from Hamari and Koivisto (2013). Independent variables, Health Conciousness, Price Consciousness and Traceability are taken from sources as follows, Gould (1988), Lichtenstein, Ridgway and Netemeyer (1993), Spielman (2015), respectively and Freshness \&Taste and Social Responsibility are adapted from Frash, DiPietro and Smith (2015). Dependent variable Local Retailer Shopping Loyalty is taken from Hozier and Stem (1985).

Table 1: Measures and Items

\section{Construct and Measurement Item}

All things considered, I find buying food produced this way to be a wise thing to do.

All things considered, I find buying food produced this way to be a good idea.

All things considered, I find buying food produced this way to be a positive thing.

All things considered, I find buying food produced this way to be favorable.

Health Consciousness $\overline{\mathbf{X}}=3,96 \sigma=0,77$

I'm very self-conscious about my health.

I'm constantly examining my health.

I'm alert to changes in my health.

I'm usually aware of my health.

I notice how I feel physically as I go through the day.

I'm very involved with my health.

\section{Price Consciousness $\overline{\mathbf{x}}=3,97 \sigma=0,84$}

I am not willing to go to extra effort to find lower prices.

I will grocery shop at more than one store to take advantage of low prices.

The money saved by finding lower prices is usually not worth the time and effort.

I would never shop at more than one store to find low prices.

The time it takes to find low prices is usually not worth the effort.

Freshness and Taste $\overline{\mathbf{X}}=4,19 \sigma=0,85$

Locally produced food is riper.

Food from local sources tastes better.

I buy local foods because they are fresher.

The closer the food is grown, the better it will taste.

Traceability $\overline{\mathbf{X}}=3,82 \sigma=0,83$

It is important for me to know the origin of the products that I purchase.

It is important for me to know the origin of the products that I eat.

I am more willing to shop at a store that sells products with a food traceability label.

Local Retailer Shopping Loyalty $\overline{\mathrm{X}}=3,97 \boldsymbol{\sigma}=0,91$

I will pay slightly more for products if I can buy them locally.

I shop locally because the convenience outweighs the other advantages of shopping outside the community.

Shopping at local stores is an enjoyable experience.

Because I am more familiar with local stores, I prefer shopping locally than out of town.

I shop locally even when the selection/variety of goods is poor.

I am loyal to my local shopping area.

Social Responsibility $\overline{\mathbf{x}}=3,92 \sigma=0,71$

When I purchase food grown locally, I feel more socially responsible.

I purchase local food because it builds community relationships.

Supporting my community is the right thing to do, so I buy food from local sources.

\section{Reference}

Hamari and Koivisto, 2013

Gould, 1988

Lichtenstein, Ridgway and Netemeyer, 1993

Frash et al., 2015

Spielman,2015; Chang, Tseng and Chu, 2013

Hozier and Stem,1985

Frash et al., 2015 
I feel like a better person when I purchase local foods.

Purchasing local foods injects more money into the community.

\section{RESULTS}

\subsection{Characteristics of Sample}

The majority of the respondents was between 35 and 44 years old $(53,5 \%)$, had a bachelor's degree $(36,2 \%)$. Almost half of the participants prefer to purchase locally produced food few times in a week $(49,2 \%)$. Detailed data about the participants is presented in Table 2.

Table 2: Demographic Profile of the Sample

\begin{tabular}{|c|c|c|}
\hline & Frequency & Percentage (\%) \\
\hline \multicolumn{3}{|l|}{ Gender } \\
\hline Male & 154 & 51.5 \\
\hline Female & 145 & 48.5 \\
\hline \multicolumn{3}{|l|}{ Age } \\
\hline $18-27$ & 3 & 1 \\
\hline $28-37$ & 35 & 11.7 \\
\hline $38-47$ & 160 & 53.5 \\
\hline $48-57$ & 87 & 29.1 \\
\hline $58+$ & 14 & 4.7 \\
\hline \multicolumn{3}{|c|}{ Local Food Purchase Frequency } \\
\hline Every Day & 39 & 13 \\
\hline Few Times a Week & 147 & 49.2 \\
\hline Few Times a Month & 104 & 34.8 \\
\hline Few Times a Year & 9 & 3 \\
\hline \multicolumn{3}{|l|}{ Education } \\
\hline Elementary School & 18 & 6 \\
\hline High School & 87 & 29 \\
\hline Associate Degree & 46 & 15.4 \\
\hline Bachelor's Degree & 108 & 36.2 \\
\hline Master's Degree & 32 & 10.7 \\
\hline Ph.D. Degree & 8 & 2.7 \\
\hline Total & 299 & 100 \\
\hline
\end{tabular}

\subsection{Factor Analysis, Reliability and Validity Tests}

In order to conduct factor analysis, variables of a structure must have a certain degree of relationship and sample has to be large enough to support this structure. In order to test the integrity of variables in the structure Bartlett Sphericity test and to decide whether sample is large enough, kaiser-meyer-olkin measure of sampling adequacy was used. According to results, KMO has a value of 0,741 , showing that sample is sufficiently large. On the other hand, Bartlett Sphericity test returned a result with 0,01 significance level thus, variables have enough relationship integrity to perform factor analysis (Nakip, 2003: 408-410). Consequently, data set is found to be suitable for factor analysis.

Factor analysis: According to the factor analysis, all items are loaded properly to their factors (see Table 3). Also definition rate that was formed by seven factors is satisfactory, considering the total variance that explained over $65 \%$ as a result of factor analysis. On the other hand, variances explained by each of the variables are between 4,713 and $18,050 \%$.

Reliability: Cronbach's alpha (CRA) value is commonly used to evaluate the internal consistency of measures. For factors to be considered inner-consistent, values equal to or higher than 0.7 are generally considered adequate (Hair et al., 2010:123). Inter-item reliability (Cronbach's Alpha) values of the items were examined to control reliability of the variables. Cronbach's alpha values are between 0.708 and 0.906 which means an acceptable internal consistency for all constructs in our study (Hair et al., 2010:125). In the same way, composite reliability values vary between 0,781 and 0,914 , confirming the internal consistency of measures. 
Validity: Construct validity consists of convergent validity and discriminant validity. Convergent validity is investigated through composite reliability, average variance extracted and factor loadings. Composite reliabilities of the items should be greater than 0.6 (Bagozzi\&Yi, 1988:80) and AVE values should greater than 0.5. In addition, all loadings should be significant. Because it provides all the convergent validity criteria mentioned above, the study has convergent validity for all constructs (Lee and Jeyong, 2014:53). In order to detect discriminant validity of constructs, Fornell\& Larcker (1981:41) criterion was used. According to this criterion, square root AVE values of each variable have to be greater than correlations between the constructs. As relevant data shown in the Table 4, the model has discriminant validity. Consequently, research model has acceptable construct validity and it is theoretically meaningful and statistically acceptable.

Table 3: Factor Analysis and Reliability Test

\begin{tabular}{lccccc}
\hline Variables & $\begin{array}{c}\text { Number of } \\
\text { Question }\end{array}$ & $\begin{array}{c}\text { Factor } \\
\text { Explained (\%) }\end{array}$ & $\begin{array}{c}\text { Factor Loadings } \\
\text { Cronbach- } \\
\text { Alpha }\end{array}$ & $\begin{array}{c}\text { Composite } \\
\text { Reliability }\end{array}$ \\
\hline Soc. Responsibility & 5 & 18,050 & $0,485-0,744$ & 0,708 & 0,781 \\
Heath Cons. & 6 & 11,894 & $0,574-0,711$ & 0,767 & 0,817 \\
Price Cons. & 5 & 9,557 & $0,556-0,865$ & 0,841 & 0,872 \\
Freshness\& Taste & 4 & 8,439 & $0,695-0,906$ & 0,849 & 0,885 \\
Traceability & 3 & 7,103 & $0,667-0,918$ & 0,829 & 0,829 \\
Locavore Attitude & 4 & 5,982 & $0,527-0,841$ & 0,754 & 0,790 \\
Local R.S. Loyalty & 5 & 4,713 & $0,786-0,868$ & 0,906 & 0,914 \\
\hline Note Factor loadings are rotated with varimax method & & & &
\end{tabular}

Note: Factor loadings are rotated with varimax method.

The mean values between 3,823 and 4,040, and the standard deviations which smaller than 1 , show that the answers that given to questionnaire are consistent. Correlation coefficients are used to observe the relationships strengths between variables (Kalayc1, 2014). According to the correlation analysis, the highest correlation was observed between the variables of Social Responsibility and Local Retailer Shopping Loyalty $(\mathrm{r}=0,395)$, and the lowest correlation was observed between the Social Responsibility and Freshness\& Taste $(r=0,016)$. In addition, there are significant correlations at ,01 and ,05 levels between all variables. Correlation coefficients shows that all of the relationships between the independent variables are lower than the acceptable value of 0,700 (Sipahi, Yurtkoru and Çinko, 2006:145).

Table 4: Correlations and Validity Test

\begin{tabular}{ccccccccc}
\hline & & \multicolumn{7}{c}{ Correlation Between Variables and Square Root of AVEs } \\
\cline { 3 - 9 } Variable & AVE & $\begin{array}{c}\text { Soc. } \\
\text { Responsibility }\end{array}$ & $\begin{array}{c}\text { Health } \\
\text { Cons. }\end{array}$ & $\begin{array}{c}\text { Price } \\
\text { Cons. }\end{array}$ & $\begin{array}{c}\text { Freshness } \\
\text { Taste }\end{array}$ & Traceability & $\begin{array}{c}\text { Locavore } \\
\text { Attitude }\end{array}$ & $\begin{array}{c}\text { Local R.S. } \\
\text { Loyalty }\end{array}$ \\
\hline Soc. Responsibility & 0,521 & $\mathbf{0 , 7 2 2}$ & & & & & & \\
Health Cons. & 0,524 & 0,355 & $\mathbf{0 , 7 2 4}$ & & & & & \\
Price Cons. & 0,619 & 0,082 & 0,124 & $\mathbf{0 , 7 8 6}$ & & & & \\
Freshness\& Taste & 0,696 & 0,016 & 0,385 & 0,181 & $\mathbf{0 , 8 3 4}$ & & & \\
Traceability & 0,767 & 0,115 & 0,039 & 0,081 & 0,023 & $\mathbf{0 , 8 7 6}$ & & \\
Locavore Attitude & 0,588 & 0,302 & 0,226 & 0,125 & 0,141 & 0,284 & $\mathbf{0 , 7 6 7}$ & $\mathbf{0 , 8 5 3}$ \\
Local R.S.Loyalty & 0,728 & 0,395 & 0,393 & 0,100 & 0,177 & 0,156 & 0,174 & \\
\hline
\end{tabular}

Note: Numbers shown in bold are Square Root of Average Variance Extracted of each item.

\subsection{Regression Analysis}

Multiple regression analysis that was used in the study is the regression analysis in which two or more independent variables are used and it aims to determine the values of the parameters of the objective regression equation. Multiple regression analysis generalizes the simple linear regression model by allowing for many terms in a mean function rather than just one intercept and one slope (Weisberg, 2005:47). Attitude Towards Locally Produced Foods variable is the control variable of the research. Two different regression analyses were performed based on the mean value of the control variable. Effects of the independent variables on the dependent variable were observed according to the control variable.

Table 5: Regression Analysis Results

\begin{tabular}{lcccc|cccc}
\hline & \multicolumn{4}{c}{ Attitude $>$ 4.04 } & \multicolumn{3}{c}{ Attitude<4.04 } \\
\cline { 2 - 9 } Independent & \multirow{2}{*}{ Std.Beta } & $\mathbf{t}$ & Sig. & VIF & Std.Beta & t & Sig. & VIF \\
\hline Soc. Responsibility & $\mathbf{3 3 7 * * *}$ & 4,582 &, 000 & 1,270 & $\mathbf{2 4 1} * * *$ & 2,720 &, 003 & 1,259 \\
Health Cons. & $\mathbf{3 5 0 * * *}$ & 4,717 &, 000 & 1,305 & $\mathbf{2 5 0} * * *$ & 2,938 &, 001 & 1,213
\end{tabular}




\begin{tabular}{|c|c|c|c|c|c|c|c|c|}
\hline Price Cons. &, $183 * *$ & 2,188 &, 030 & 1,182 &, 081 & 0,954 & ,342 & 1,114 \\
\hline Freshness\& Taste &, $228 * * *$ & 3,254 & 004 & 1,166 & ,159* & 1,682 &, 062 & 1,045 \\
\hline Traceability &, $209 * * *$ & 3,096 &, 008 & 1,084 & ,091 & 1,009 & ,305 & 1,114 \\
\hline Adj R Square & \multirow{2}{*}{\multicolumn{4}{|c|}{$\begin{array}{c}0,324 \\
12.585\end{array}$}} & \multicolumn{4}{|c|}{0,244} \\
\hline $\mathrm{F}$ & & & & & \multicolumn{4}{|c|}{8,212} \\
\hline
\end{tabular}

Note 1: Dependent Variable: Local R.S. Loyalty

Note 2: *** shows significance of 0,01; ** of 0,05 and * of 0,10.

Note 3: Value 4,04 indicates the mean of attitude towards locally produced food throughout the sample.

According to the regression analysis which the attitudes towards locally produced foods is high, it was observed that all the factors except price consciousness are significant at, 01 level and price consciousness factor is significant at, 05 level on local retailer shopping loyalty. The $F$ value which indicates the significance of the model, is found to be $12,585^{* * *}$, which is an indication that our model is significant as a whole. The Adjusted $\mathrm{R}^{2}$ value is a measure of how much of the change in the dependent variable can be explained by the independent variables. The Adjusted $\mathrm{R}^{2}$ was measured as 0,324 which means independent variables of the research explain $\% 32$ of the change in dependent variable (Kalayc1, 2014:267). Variance Inflation Factors (VIF) were observed less than 3 that means analysis do not have any multicollinearity problem (Kalayc1, 2014:268). According to standardized beta coefficients which explain the relative effect of the independent variables on the dependent variable, all variables (Social Responsibility and Freshness\& Taste) will affect the local retailer shopping loyalty positively consistent with the literature.

According to the regression analysis which the attitudes towards locally produced foods is low, the value of $\mathrm{F}\left(8,212^{* * *}\right)$ shows that the model is meaningful as a whole. The Adjusted $\mathrm{R}^{2}$ was measured as 0,244 which means independent variables explain $\% 24$ of the change in local retailer shopping loyalty and it was observed that all VIF values are less than 3. Beta coefficients shows that health consciousness, social responsibility and freshness\& taste factors have positive and significant effect on local retailer shopping loyalty, but price consciousness and traceability factors don't have significant effect on loyalty.

\section{DISCUSSION AND CONCLUSION}

\subsection{Discussion}

There has been substantial attention and growth surrounding sustainable foods recently. As a result, explaining, predicting consumer behavior and investigating different factors in this area of research has become a necessity. Local food production is one of these sustainable innovations that has been mentioned in the literature (Feenstra,1997). Additionally, it is a vital issue which is associated with green marketing (Grant, 2007).

In this context of preceding argument, in this paper we tried to measure people's degree of loyalty towards the organizations that sells locally produced food. In order to achieve this goal, several antecedents were hypothesized to positively affect the loyalty. Furthermore, according to Feldmann and Hamm (2015), attitudes are important predictors of local food purchase behavior. Hence, attitude towards locally produced food was integrated as a control variable into our model.

Results derived from the structural equation modeling, confirmed that attitude is indeed an important indicative of locavorism. What is more important, loyalty is significantly affected by health concerns and social responsibility. Findings substantiate that people mostly feel loyalty out of social responsibility and health concerns. Previous studies emphasize that health and price consciousness, traceability, freshness\& taste and social responsibility activities have linear and positive effect on loyalty. Results shows that all these factors positively affect loyalty congruous with literature (Haenfler, Johnson and Jones 2012; Rainbolt, Onozaka and McFadden, 2012). Although the results are coherent with previous research, a surprising result has emerged. It was discovered that social responsibility activities are effective on loyalty as much as health. Locavorism is a social movement itself and involving production of fresh, healthy food for everyone may be the reason of its impressive effect on loyalty.

It is believed that farmers and small food enterprises constitute the backbone of food provisioning for communities. Concurrently, it has been mentioned that how processes within the local agriculture (agroecology, permaculture etc.) provide healthy, sustainable and productive food for communities (Macias, 2008). Therefore, especially today while these kinds of pragmatic ideas gain importance every day, it is considered that this study 
will be beneficial for society, academicians and practitioners.

Sample selection is the limitation of our research. The sample of the study was formed by the people who reside in Istanbul and Kocaeli. Industrial activities are the primary revenue sources of Istanbul and Kocaeli but food production is limited and this situation makes it harder to reach locally grown foods for those living there. Therefore, more rural regions which engaged in agriculture should select for exhaustive results in further studies.

\section{REFERENCES}

1.Bagozzi, R. \& Yi, Y. (1988), On the Evaluation of Structural Equation Models, Journal of the Academy of Marketing Science, 16, pp.74-94.

2.Becker, M. H., Maiman, L. A., Kirscht, J. P., Haefner, D. P., \& Drachman, R. H. (1977) The Health Belief Model and Prediction of Dietary Compliance: A Field Experiment. Journal of Health and Social Behaviour, 18, pp.348-366.

3.Choe, Y. C., Park, J., Chung, M., \& Moon, J. (2009). Effect of the Food Traceability System for Building Trust: Price Premium and Buying Behavior. Information Systems Frontiers, 11(2), pp.167-179.

4.Clark, M. A., \& Wood, R. C. (1998). Consumer Loyalty in the Restaurant Industry-A Preliminary Exploration of the Issues. International Journal of Contemporary Hospitality Management, 10(4), pp.139-144.

5.Conner, D. S., Montri, A. D., Montri, D. N., \& Hamm, M. W. (2009). Consumer Demand for Local Produce at Extended Season Farmers' Markets: Guiding Farmer Marketing Strategies. Renewable Agriculture and Food Systems, 24(04), pp.251-259.

6.Chang, A., Tseng, C. H., \& Chu, M. Y. (2013). Value Creation from a Food Traceability System Based on a Hierarchical Model of Consumer Personality Traits. British Food Journal, 115(9), 1361-1380.

7.Dovalienè, A., \& Virvilaite, R. (2008). Customer Value and Its Contribution to the Longevity of Relationship with Service Provider: The Case of Theatre Industry. Engineering Economics, (1 (56)), pp.66-73.

8.Drewnowski, A. (1997). Taste preferences and food intake. Annual Review of Nutrition, 17(1), pp.237-253.

9.Espejel, J., Fandos, C., \& Flavian, C. (2008). Consumer Satisfaction: A Key Factor of Consumer Loyalty and Buying Intention of a PDO Food Product. British Food Journal, 110(9), 865-881.

10.Feenstra, G. W. (1997). Local Food Systems and Sustainable Communities. American Journal of Alternative Agriculture, 12(01), 28-36.

11.Feldmann, C., \& Hamm, U. (2015). Consumers' Perceptions and Preferences for Local Food: A Review. Food Quality and Preference, 40, 152-164.

12.Fornell, C. \& Larcker, D.F. (1981), Evaluating Structural Equation Models with Unobservable Variables and Measurement Error. Journal of Marketing Research. 18(1), 9-50.

13.Food Marketing Institute (1996). Trends in the United States: Consumer Attitudes and the Supermarket. Chicago: Food Marketing Inst.

14.Frash Jr, R. E., DiPietro, R., \& Smith, W. (2015). Pay more for McLocal? Examining Motivators for Willingness to Pay for Local Food in A Chain Restaurant Setting. Journal of Hospitality Marketing \& Management, 24(4), 411434.

15.Hobbs, J.E., Bailey, B.V., Dickinson, D.L. and Haghiri, M. (2005), "Traceability in the Canadian Red Meat Sector: Do Consumers Care?", Canadian Journal of Agricultural Economics, Vol. 53 No. 1, pp. 47-65.

16.Huber, F., Herrmann, A. and Wricke, M. (2001), "Customer Satisfaction as an Antecedent of Price Acceptance: Results of an Empirical Study", Journal of Product \& Brand Management, Vol. 10 No. 3, pp. 160-9.

17.Gibson, E. L. (2006). Emotional Influences on Food Choice: Sensory, Physiological and Psychological Pathways. Physiology \& behavior, 89(1), 53-61.

18.Giovannucci, Daniele, Elizabeth Barham, Rich Pirog. 2009. Defining and Marketing 'Local' Foods: Geographical Indications for U.S. Products. Journal of World Intellectual Property special issue on GIs. 
19.Gould, S. J. (1988). Consumer Attitudes Toward Health and Health Care: A Differential Perspective. Journal of Consumer Affairs, 22(1), 96-118.

20.Grant, J. (2007). Green Marketing Manifesto, John Wiley \& Sons Ltd, England.

21.Grewal, D., Iyer, G. R., Krishnan, R., \& Sharma, A. (2003). The Internet and the Price-Value-Loyalty Chain. Journal of Business Research, 56(5), 391-398.

22.Haenfler, R., Johnson, B., \& Jones, E. (2012). Lifestyle Movements: Exploring the İntersection of Lifestyle and Social Movements. Social Movement Studies, 11(1), 1-20.

23.Hair, J.F., Black, W.C., Babin, B.J. \& Anderson, R. E. (2010), Multivariate Data Analysis. 7th Edition. Pearson Education. New Jersey.

24.Hamari, J., \& Koivisto, J. (2013). Social Motivations to Use Gamification: An Empirical Study of Gamifying Exercise. In Proceedings of the 21st European Conference on Information Systems, Utrecht, Netherlands, June 5-8, 2013.

25.Harman, H. H. (1976). Modern Factor Analysis. Chicago, IL: University of Chicago Press.

26.Hozier, G. C., \& Stem, D. E. (1985). General retail patronage Loyalty as a Determinant of Consumer Outshopping Behavior. Journal of the Academy of Marketing Science, 13(1-2), 32-46.

27.Jones, D.: 1997, ‘Good Work, Good Business’, USA Today, April, 25, 1 B.

28.Kalaycı, Ş. (2014). SPSS Uygulamalı Çok Değişkenli Istatistik Teknikleri, 6. Baskı, Asil Yayın Dağıtım, Ankara.

29.Kearney, M., Kearney, J. M., Dunne, A., \& Gibney, M. J. (2000). Sociodemographic Determinants of Perceived Influences on Food Choice in a Nationally Representative Sample of Irish Adults. Public Health Nutrition, 3(02), 219-226.

30.Krystallis, A., \& Chrysochou, P. (2011). Health Claims as Communication Tools that Enhance Brand Loyalty: The Case of Low-Fat Claims within the Dairy Food Category. Journal of Marketing Communications, 17(3), 213-228.

31.Lages, L. F., Jap, S. D., \& Griffith, D. A. (2008), The Role of Past Performance in Export Ventures: A Short-Term Reactive Approach, Journal of International Business Studies, 39(2), 304-325.

32.Lee, S. A., \& Jeong, M. (2014), Enhancing Online Brand Experiences: An Application of Congruity Theory. International Journal of Hospitality Management, 40, 49-58.

33.Lichtenstein, D. R., Ridgway, N. M., \& Netemeyer, R. G. (1993). Price Perceptions and Consumer Shopping Behavior: A Field Study. Journal of Marketing Research, 234-245.

34.Macias, T. (2008). Working Toward a Just, Equitable, and Local Food System: The Social İmpact of Community - Based Agriculture. Social Science Quarterly, 89(5), 1086-1101.

35.Maignan, I. and O. C. Ferrell: 2001, 'Corporate Citizen as a Marketing Instrument - Concepts, Evidence and Research Directions', European Journal of Marketing 35(3/4), p. 457-484.

36.Malhotra, N. K., Kim, S. S., \& Patil, A. (2006), Common Method Variance in IS Research: A Comparison of Alternative Approaches and A Reanalysis of Past Research. Management Science, 52(12), 1865-1883.

37.Marin, L., Ruiz, S., \& Rubio, A. (2009). The Role of Identity Salience in the Effects of Corporate Social Responsibility on Consumer Behavior. Journal of Business Ethics, 84(1), 65-78.

38. Menachemi, N. (2011), Assessing Response Bias in a Web Survey at a University Faculty. Evaluation \& Research in Education. 24(1), 5-15.

39.Michaelidou, N., \& Hassan, L. M. (2008). The Role of Health Consciousness, Food Safety Concern and Ethical Identity on Attitudes and Intentions Towards Organic Food. International Journal of Consumer Studies, 32(2), 163-170.

40.Nakip, Mahir (2003) Pazarlama Araştırmaları, 1. Baskı, Ankara, Seçkin Yayıncılık. 
41.Podsakoff, P.M. \& Organ, D.W., (1986), Self-Reports in Organizational Research: Problems and Prospects. Journal of management, 12(4), 531-544.

42.Podsakoff, P. M., Mackenzie, S. B., Lee, J. Y., \& Podsakoff, N. P. (2003), Common Method Biases in Behavioral Research: A Critical Review of The Literature and Recommended Remedies. Journal of Applied Psychology, 88(5), 879-903.

43.Quinn, M. (2013). Locally Grown/Locally Raised. In Encyclopedia of Corporate Social Responsibility (pp. 15981602). Springer Berlin Heidelberg.

44.Rainbolt, G., Onozaka, Y., \& McFadden, D. T. (2012). Consumer Motivations and Buying Behavior: The Case of the Local Food System Movement. Journal of Food Products Marketing, 18(5), 385-396.

45.Salmones ,M.G., Crespo, A. H., \& Del Bosque, I. R. (2005). Influence of Corporate Social Responsibility on Loyalty and Valuation of Services. Journal of Business Ethics, 61(4), 369-385.

46.Schifferstein, H. N. J., \& Oude Ophuis P. A. M. (1998). Health-Related Determinants of Organic Food Consumption in the Netherlands. Food Quality and Preference, 9 (3), 119-133.

47.Sipahi B., Yurtkoru E. S. Ve Çinko M. (2006) Sosyal Bilimlerde SPSS'le Veri Analizi, İstanbul: Beta Yayınları.

48.Spielmann, N., \& Bernelin, M. (2015). Locavores: Where You Buy Defines Who You Are. International Journal of Retail \& Distribution Management, 43(7), 617-633.

49.Stanton, J. L., Wiley, J. B., \& Wirth, F. F. (2012). Who are the Locavores?. Journal of Consumer Marketing, 29(4), 248-261.

50.Story, M., Kaphingst, K. M., Robinson-O'Brien, R., \& Glanz, K. (2008). Creating Healthy Food and Eating Environments: Policy and Environmental Approaches. Annu. Rev. Public Health, 29, 253-272.

51.Thomas, L.N. and Mcintosh, W.A. (2013), “It Just Tastes Better When İt's in Season': Understanding Why Locavores Eat Close to Home", Journal of Hunger \& Environmental Nutrition, Vol. 8, No. 1, pp. 61-72.

52.Weisberg, S. (2005). Applied Linear Regression, Third Edition, Minnesota, John Wiley \& Sons.

53.Who, J., \& Consultation, F. E. (2003). Diet, Nutrition and the Prevention of Chronic Diseases. World Health Organ Tech Rep Ser, 916.

54.Verbeke, W. and Ward, R.W. (2006), “Consumer İnterest in İnformation Cues Denoting Quality, Traceability and Origin: An Application of Ordered Probit Models to Beef Labels”, Food Quality and Preference, Vol. 17 No. 6, pp. 453-67

55.Virvilaite, R., Saladiene, V., \& Skindaras, D. (2009). The Relationship Between Price and Loyalty in Services Industry. Engineering Economics, 63(4), pp.96-104.

56.Voss, G., Parasuraman, A., \& Grewal, D. (1998). The Role of Price and Quality Perceptions in Prepurchase and Postpurchase Evaluation of Services. Journal of Marketing, 62(4), 46-61.

57.Yeon K.H., \& Chung, J. E. (2011). Consumer Purchase Intention for Organic Personal Care Products. Journal of Consumer Marketing, 28(1), 40-47.

(C) 2017 by the authors; licensee Preprints, Basel, Switzerland. This article is an open access article distributed under the terms and conditions of the Creative Commons by Attribution (CC-BY) license (http://creativecommons.org/licenses/by/4.0/). 